\title{
Consequence of Gender and Job Characteristics with Normative Commitment
}

\author{
Deepmala Shrestha
}

\begin{abstract}
The aim of this study is to investigate the existence of relationships between components of psychological climate including gender issue, autonomy, work pressure, skills used and normative commitment. This study shows that, for a sample 109 Nepalese Commercials Banks employees, one component (Normative) of organizational commitment are predicted by two characteristics that influence the commitment (personal, and Job) affected to organizational performance. Implications for future research are discussed.
\end{abstract}

Keywords: organizational commitment, personal/job characteristics, normative commitment

\section{Background}

Organizational commitment means employees, loyalty and willingness to contribute to the organization. Employee commitment is of great importance; because high levels of commitment lead to several favorable organizational outcomes. It is possible to be dissatisfied with a particular feature of a job while retaining a reasonably high level of commitment to the organization as a whole. When creating a commitment strategy, Amstrong, 1999 asserts, "It is difficult to deny that it is desirable for management to have defined strategic goals and values."

Greenberg and Baron (2000, p. 181) define organizational commitment as an "extent to which an individual identifies and is involved with his or her organization or is unwilling to leave it". It is determined by a number of individual (Gender), and job (autonomy, work pressure, skills used etc). The concept of commitment and the assumption that committed employees are beneficial to organizations has a long tradition in the management literature (Swailes, 2002), and this paper asserts that the single most useful outcome of human resource management (HRM) strategies is the creation of a high commitment workforce. Commitment is one of the important elements in the employee-organization linkage, Agarwal and Ramaswami (1993). 
More specifically, they are valuing their workforce for high performance and better results. Developing and strengthening of human capital is, therefore, essential to ensure the long-term success in today's dynamic business environment. The increasing diversity of the workforce presents myriad opportunities and challenges to U.S. organizations as well as in the entire business world. Those organizations that manage diversity effectively reap a number of positive benefits, such as increased productivity, higher rates of retention, and greater ability to recruit high-potential candidates (Loden and Rosener, 1991; Morrison, 1996).

"Be loyal to the company, and the company will be loyal to you", a credo emblematic of bygone era (Mowday, Porter, \& Steers, 1982), obviously understates the complexity involved in a persons attitude toward and behavior within his or her employing organization. Description of variables used in this research are in shown in Appendix "A"

\section{Objectives of the Study}

The main objectives of this study are to

- Examine the dimensions of personal, and job characteristics.

- Examine personal and job characteristics with normative commitment.

- Examine the relationships between personal characteristics, job characteristics and normative commitment simultaneously.

\section{Literature Review}

\subsection{Characteristics affecting commitment}

The categories of personal and job characteristics and normative commitment is described here.

\subsubsection{The relationship between $\mathrm{PC}$ and $\mathrm{OC}$}

Gender: The focus of this research is women working in the banking sector. Recent studies examining occupational distribution reveal that the number of women employed in banking has increased significantly. However, in both 2000 and 2006, the percentage of women employed by foreign banks is higher than the percentage of women employed by private banks. On personal characteristics, some earlier research has suggested those women and especially those who work part time and married women with children will have lower levels of commitment to their work than men. One set of studies reports greater organizational commitment by men (Arana et al., 1986; Baird et al., 1998; DoddMcCue and Wright, 1996; Kaldenberg et al., 1995). However, in some of these studies, 
the bivariate results lose their significance once job-related factors are entered as controls (Arana et al., 1986; Dodd-McCue and Wright, 1996). However, this relationship is disputed later on. On the other hand, Women have less opportunities with other organizations and overcome more barriers to get where they are, thus they are more likely to be committed to their organizations. Nevertheless, there are studies that report greater organizational commitment by men, even after controlling for job-related factors (Kaldenberg et al., 1995).

Another set of studies, including a meta-analysis (Matthieu and Zajec, 1990), reports greater commitment by women, a finding consistent with several subsequent individual studies (Marsden et al., 1993; Wahn, 1998). A third set of studies (Bielby and Bielby, 1989; Bruning and Snyder, 1983; Fry and Greenfeld, 1980), including another meta-analysis (Aven et al., 1993), report no sex differences in organizational commitment especially after controlling for job related variables, again with supportive evidence from individual studies conducted subsequently (Ngo and Tsang, 1998; Korabik and Rosen, 1995; Siguaw and Honeycutt, 1995). Further, a meta-analytic study by Mathieu and Zajac (1990) found that women are more affectively committed to the organization than men. Some studies suggest that since women do not enjoy a high degree of corporate power, they perceive that they have less control over their careers, and thus are more committed to their families and personal lives than their jobs or organizations (e.g. Kanter, 1968). Women are usually more committed than men to their organizations, possibly because they have to overcome more barriers to getting into those organizations or because fewer alternatives are available to them.

Kabasakal et al. (1994) found that while women employed in the banking and insurance sectors made up 43 percent of all employees, they represented only 26 percent of middle-level managers and a mere 3 percent of upper level management. A decade later Zeytinoglu et al. (2001) interviewed 432 managers in 100 manufacturing companies and found that less than 10 percent were women. Of these female managers, only 7 percent were in upper level positions while the majority 73 percent was in middle-level positions. A more recent study by Mathis and Jackson (2006) found that 82 percent of the 278 women were in middle management positions while 8.7 percent were in senior management. While these studies to evidence large gains by women, they do reflect some upward mobility. There is some speculation that this increase in female employment in banking may be temporary phenomenon's that may reverse itself once more qualified males enter the labor force.

Furthermore, it is projected that the women's labor force participation rate will 
increase to 62 percent in 2008, up from 50 percent in 1978 (US Bureau of Labor Statistics, 2000). As Furthermore, as Eagly (1987) contends, gender differences in research must be reported completely and precisely, even if there are no significant differences, and that "null findings, if obtained consistently across studies, would help establish that women and men are similar in many respects" (Eagly, 1987, p. 756).

\subsubsection{The relationship between $\mathrm{JC}$ and $\mathrm{OC}$}

Job characteristics are those attributes of the job position. These are role-related characteristics. They include autonomy, work pressure, and skills used on the job. Some points are discussed here from the literature review.

Autonomy: A similar definition of commitment emphasizes the importance of behavior in creating it. Salancik (1977) conceives commitment as a state of being in which an individual becomes bound by his actions and it is these actions that sustain his activities and involvement. From this definition, it can be inferred that three features of behavior are important in binding individuals to act: visibility of acts, the extent to which the outcomes are irrevocable; and the degree to which the person undertakes the action voluntarily. To Salancik therefore, commitment can be increased and harnessed to obtain support for the organizational ends and interests through such things as participation in decision-making.

Autonomy is thought to be one of the most powerful indicators of organizational commitment. Researchers have found that the more control and freedom a worker has, the more likely that worker is to be committed to the organization. In the same token, workers who are under supervision are more likely to be less committed. Autonomy is the respondent's ability to work independently, make decisions, and control what happens in their job and the closeness of their supervision. Measurability of output involves how easy it is for the respondent's supervisor to evaluate the quantity and quality of work produced. An empirical study has been done in participation in decision-making and found that the higher the participation in decision-making, the higher will be the employee commitment.

Work pressure: There is little research on the effect of hours worked on organizational commitment. The measure of work pressure used looks at the general intensity of work - both physical and mental - and time pressures. However, it follows that workers who work longer hours would be less committed to their organization. The potential influence of shorter hours of work was considered to be more committed. Longer hours of work 
through regular overtime might be expected to produce either more commitment through the employee appreciating the income-increasing opportunities, or lower commitment if it is associated with unwanted pressure to work longer hours.

Skills used on the job: It is simply understandable that if organization is respecting the degree of skills of an employee and is more in use then the employee commitment is higher. On the other side; using their skills means encouraging them to be more competent and in general sense when employee is competent enough they are less likely to be committed because they search for new-new organization. Simply, competent employees do not remain in one organization just because they are more opportunistic. Hence there is no such empirical research done in this part.

\subsubsection{Normative Commitment}

The individual commits to and remains with an organization because of feelings of obligation. These feelings may derive from many sources. For example, the organization may have invested resources in training an employee who then feels a 'moral' obligation to put forth effort on the job and stay with the organization to 'repay the debt.' It may also reflect an internalized norm, developed before the person joins the organization through family or other socialization processes, that one should be loyal to one's organization. The employee stays with the organization because he/she "ought to". People with high degree of $\mathrm{NC}$ are greatly concerned about what other think them if they leave from organization. They are reluctant to disappoint their employers and are concerned that their fellow employees may think poorly of them for resigning. (Greenberg \& Baron, 2003). Normative commitment reflects a feeling of obligation to continue membership with the entity in question. The concept of normative commitment was originally introduced by (Wiener 1982), who argued that normative commitment should be viewed as "the totality of internalized normative pressures to act in a way that meets organizational goals and interests". Another commonly used term for normative commitment is moral commitment. Normative commitment involves a feeling of moral obligation to continue working for a particular organization. For any number of reasons, such as a feeling of indebtedness, need for reciprocity or organizational socialization, normatively committed employees feel that they ought to remain with the organization (Meyer \& Allen, 1991). NC develops on the basis of a collection of pressures that individuals feel during their early socialization from family and society (Wiener, 1982). Some of the organizational actions can make a person 
indebted toward the organization, which can build normative commitment (Gouldner, 1960). Employees with a high level of normative commitment feel that they ought to remain with the organization. Investments made by an organization in their employees that seem hard to reciprocate are also suggested to contribute to the development normative commitment (Meyer \& Allen 1991). Such an investment may be an expensive training session that the organization agrees to cover. Quality personnel may, for instance, assist a development project with tackling some specific problem. In addition, normative commitment may develop on the basis of psychological contract. Such a contract consists of "beliefs of the parties involved in an exchange relationship regarding their reciprocal obligations" (Meyer \& Allen 1997).

\section{Methods and Tools of Analysis}

Data for this research came from 109 employees (males, and females) working in different commercial banking. Questionnaires were dropped, participants are asked to fill the questionnaires and provide suggestion or feedback, and then after few days at their conveniences data's' are collected. During the time of collection, interviews were also taken for proven or support the studies. The collected survey data was processed using SPSS statistical analysis package. To reach the research goals, the following methods were employed: the levels of organizational commitment, factors affecting variables (personal and job characteristics) estimating variables was assessed by calculating the rank order correlation (Pearson, and Spearman's Rho) and chi-square to test the hypothesis as due to the small sample the distribution was not normal.

\subsection{Technique of Analysis}

For this study, the SPSS $®$ version 13.0 for Windows SPSS (c) Base 13.0Applications Guide, the statistical software program 1998, revised 2004 of September were used to perform all procedures. As a preliminary step to this data analyses, researcher examined statistical information in several areas. First, researcher analyzed the frequency and mean differences of the demographic data, job, and commitment. Second, researcher used descriptive statistics to examine the mean scores, standard deviation, and other information about all. Third, researcher conducted additional analyses to determine if there were any statistically significant differences in the mean scores for normative commitment based on demographics and job characteristics. These analyses included Pearson correlations for all 
Five Point Likert Scale (job characteristics and commitment), Spearman Rho correlations for commitment and chi-square to test the hypothesis for all excluding five point likert scale questions especially for job characteristics. Fourth, researcher examined the reliability (alphas) of job characteristics (skills used), three type of commitment (Normative) lastly, and researcher examined correlation for each variable.

\subsection{Instrumentation}

Personal characteristic variables included in this study were gender (male $=1$, Female $=2$ ). A total of 109 employees of different commercial banks were chosen at various levels of employees excluding low level of employees across Pokhara and Kathmandu comprised the sample for this study. Nearly more than half of the sample $(56.9 \%)$ was male, and the nearly half of the average age was 33.83 years $(S D=6.45)$. The frequency, mean, S.D of gender is shown in Appendix "B"

Job characteristics factors included opportunity to make decision (Yes $=1$ and No $=0)$, extent to which one feel free to make decision ( $1=$ no independent, $2=$ below average independent, 3 = average, 4 = above average independent and $5=$ fully independent), one feel responsible in making decision (yes $=1, \mathrm{No}=0$ ), enjoy working in time pressure (yes $=1$ and $0=\mathrm{No}$ ), extend to which their work relate to the position ( $1=$ not at all relate to the position, $2=$ below average to position, $3=$ average, $4=$ above average and $5=$ fully relate to position), like wise others questionnaire are also coded in the same manner but overall the 1 is the lowest degree whereas 5 is the highest or the strongest part for each question follows to whole questions relate to Yes/No or 5 point likert scale.

Organizational Commitment, Normative commitment used 5-point Likert Scale and so here $1=$ lowest and 5=strongest was used. "One of the major reasons that this research continue to work here is that, "I believe that loyalty is important and therefore, feel a sense of moral obligation to remain" (Normative Commitment Scale) on a 5-point scale ranging from Strongly Agree (5) to Strongly Disagree (1). Following the advice of the survey authors and supervisor, the questions were presented in organized order. Besides given limited time and monetary resources available to conduct the research, the data collection was based on random sampling. Normative commitment self questionnaire were added with the idea of \& were measured with the scales developed by Allen and Meyer (1990) and modified by Meyer et al. taken from Stallworth (2003) (examples of item: Jumping from organization to organization does not seem at all unethical to me). 


\subsection{Data Analysis}

\subsubsection{Factors affecting commitments}

The dimension of personal and job characteristics are measured statistically using correlation to view the relationship between the variables and chi-square to test the hypothesis.

Personal characteristics: There is no association shown between gender and level of normative commitment, above average male $\left(64.5 \%\right.$ where $1^{2}=1.919$ and $p=.383$ the correlation between gender and normative commitment is negatively related $(\mathrm{r}=-0.05)$.

Summary: The level of gender has no relation nor is significance with the level of commitment.

Job Characteristics: The hypothesis that, the higher the opportunity given to make decision the higher will be the attachment to the organization with the sense that their moral will be high for the freedom to get chance to decide on their own is accepted. Above than the average respondent (69\%) have given their view that they have independence to make certain level of decision regarding property evaluation report and employees appraisal to be believed and based on that information head office finalize on sanctioning loan and rewarding/punishing employees (branch office). However, branch manager of head office have same level of freedom to make decision as done by BM of branch offices. The research found the hypothesis not associated with $1^{2}=.211, p=.900(p>0.05)$ of normative at above average (64.4\%).

The concept from the literature, the hypothesis that higher the pressure lower will be the commitment here in case normative, the association between employee enjoying to work in pressure at above average (67\%) is highly positive and is significant at $1^{2}=9.780$, $\mathrm{p}=0.008$.

The concept skills used of employees' is not matched with obligation (normative commitment). A complete opinion survey was also taken asking, "What further skill you need to improve your job done?" followed by below answer are presented in table 1.1.

Table 1.1 . Expectation of skills from banks

\begin{tabular}{|l|c|c|}
\hline Expectation of skills employees' demanding from their organization & Frequency & Valid (\%) \\
\hline Advanced training & 11 & 10.1 \\
\hline Banking skill & 11 & 10.1 \\
\hline Communication skill & 14 & 12.8 \\
\hline Credit analysis & 1 & .9 \\
\hline EMBA & 3 & 2.8 \\
\hline
\end{tabular}




\begin{tabular}{|l|c|c|}
\hline English language and banking training & 1 & .9 \\
\hline International banking & 8 & 7.3 \\
\hline Leadership skill & 5 & 4.6 \\
\hline Managerial skill & 13 & 11.9 \\
\hline Marketing skill & 2 & 1.8 \\
\hline Operation methods & 1 & .9 \\
\hline Team work & 1 & .9 \\
\hline Technical skill & 21 & 19.3 \\
\hline Total & 109 & 100.0 \\
\hline
\end{tabular}

From the study it can be seen that employees are more interested for technical skills $(19.3 \%)$, which means the area learn that may support for particular performance to be done is important. It is not the matter of manual things done for transaction but handling customer being head office or related to HR department, one has to have good communication skill. Therefore, $13 \%$ are expecting communication skill to be improved. The survey is done in managerial level and middle level; therefore, $12 \%$ wanted their managerial skill to be sharpened. As such the success and the failure of the organization are dependent on an individual who are directly related to that field. Manager has to directly deal with communication, convincing and control system. Degree holder employees are more competent enough and so are opportunistic. Banks are recruiting people in a responsible post for higher degrees', if a person is experienced enough then that is added as a additional factor. However, experienced with bachelor degree are also working in a responsible post. In banking sector experienced counts a lot. Since then in order to compete the change, updated with info, get exposed to market and can challenge the fresher with energetic personality, existing non-degree holder wants to do executive MBA from reputed institution, few of them have already joined the program. So, respondents are interested for upgrading their educational career also.

Summary: From the statistically analysis done above for job characteristics and organizational commitment (normative), it is found that organizational commitment is highly affected by job characteristics.

\section{Results}

Results of the survey were first analyzed using frequency, descriptive statistics, and reliability analysis. The research question was explored using correlations and chisquare 
analyses. The correlations were used to test relevant inter-relationships. However, these univariate results are not generally very robust, thus it was not necessary to use hierarchical regression analyses to assess the unique effects of variables. First, the job-related and demographic variable (other than gender) was entered and the effects measured on each job attitude. Gender was then entered and its unique effects assessed. Surveys from 109 participants were received.

From the research, that is not associated with normative commitment shows that obligation (normative) is not influenced by the opportunity given to make decision. The communication and employees' pattern are changing with the change of organizational environment from then to now in banking sector. So, for the analysis of communication and their pattern used, two basic issues are vital, i.e. i) to whom they formally briefing of business strategy, financial performance, and organizational work are made, and ii) how the employees communicate their views to their superior. According to the information been provided by the respondent of this research, it is found that in Nepalese context of commercial bank the business strategies are generally communicated and briefed to management employees. But unfortunately, the clerical and middle level staffs are not communicated about the business strategies.

Researcher examined the reliability (Cronbach's alpha) of job characteristic (Skills used), and commitments (normative commitment) shown in table 1.2.

Table 1.2 Alpha coefficient (a), mean, standard deviation, and independent variables

\begin{tabular}{|c|c|c|c|c|}
\hline Variables & & Mean & S $>$ D & Alpha (a) \\
\hline OC & & & & \\
\hline & NC & 3.7156 & .839 & .417 \\
\hline $\begin{array}{c}\text { Skilled used } \\
\mathbf{N}=\# 109\end{array}$ & & & & .829 \\
\hline
\end{tabular}

Note: \# $\mathrm{N}$ is the number of cases with non-missing values

\#\# $\mathrm{N}$ is the number of cases with missing values

From table 1.2 the reliability of the normative commitment scale's Cronbach's was 0.417 for items four. Reliability for skills used of employees the Cronbach's Alpha (a) is .829 and the no of Items 3.

Results for skilled used: individual perception on their ability and potential being completely appreciated is .818 , individual thinking their skill being matches with their given job is .707, extent to which respondent feel motivated using their skill in job.765. From among the item 8 all 5 items were deleted because of the greater values. Three items 
are in use, which score for Cronbach's Alpha as .417 for normative commitment.

Table 1.3 Descriptive statistics for organizational commitment measures

\begin{tabular}{|l|l|l|l|}
\hline \multicolumn{1}{|c|}{ Items } & N & M & SD \\
\hline Normative Commitment & & & \\
\hline $\begin{array}{l}\text { I think that people these days move from company to } \\
\text { company too often }\end{array}$ & 109 & 4.07 & .997 \\
\hline $\begin{array}{l}\text { Jumping from organization to organization does not seem } \\
\text { at all unethical to me }\end{array}$ & 109 & 3.42 & 1.234 \\
\hline $\begin{array}{l}\text { One of the major reasons that I continue to work here is } \\
\text { that I believe that loyalty is important and therefore, feel a } \\
\text { sense of moral obligation to remain }\end{array}$ & 109 & 3.62 & 1.153 \\
\hline
\end{tabular}

\section{Discussion and Conclusion}

Nepalese business organizations especially the banking sector are no longer untouched and uninfluenced from global trend of increasing competition, rapid change in technology and demand for competent and multi-skilled workforce. Consequently, they are experiencing a stiff domestic as well as external competition with rising demand for trained and skilled manpower. Analyzing the Nepalese context, Agrawal (1999) observes that human resource development has remained an area of least priority in Nepalese organizations. An attempt, therefore, has been made here to study the human resources development practices in business organizations of Nepal with a due focus on identifying development opportunities (appreciating ideas, given discretion to work on their own as an independent individualism, encouraging them to work in time and motivated in the same sense and taking care of skills needed to sharpen their personality for better performance) provided for employees, measuring investment made on them, and examining consequences of providing such opportunities in an organization.

In addition to the reduction of employee turnover, employee organizational commitment is also thought to be essential for quality improvement (Schuler and Jackson, 1999), which implies a necessity to develop employee commitment in the upscale banking sector that seeks competitive advantage through the quality enhancement strategy. The research also maintains the importance of such human resource practices as appropriate feedback systems, teamwork, and delegation of relevant decision-making and responsibility to each employee. Even though other factors are also involved, commitment to the organization is probably most reflective of how employees feel about other categories of 
variables affecting commitment like personal (Gender), job (Autonomy, work pressure, skills used) on normative commitment. Additionally, this study offers additional insight into how this commitment affects the performance level. These characteristics focus on the quality of the relationship of employees with organization to be highly committed. Mowday et al. (1982) concluded that highly committed employees wish to remain with their employing organizations. Moreover, it is found from the research on an interview process and argue on "when I am getting what I am contributing then why not the same level of my effort and skills can be used to other organization if I got better opportunity than here. Such strong commends are provided by deputy and branch head. Individuals on banking sector are looking forward for upgrading their position other than running for money.

They believe "money is something a basic needs" that every individual wants but here in the case (Deputy Head, BM and Executives level) there is a competition for position/status. Market has forced me to think and to compare myself with my colleagues or batch mate of my degree level, they replied when asked, "Why are you so competent and are looking for other option?"

Employee relation and communication in Nepalese commercial banks covers according to the information avail by the managers in an interview, employee communication plays vital role in decision-making, implementation, and eventually in organizational performance. Therefore, naturally in employee's communication there is less flexibility in Nepalese banking sector. However, the propensity of employee communication is found increasing. From the interview taken, it is clear that Nepalese banks are using diverse communication methods, however about half of the employees are not experiencing the liberal use of such communication

Human resources in Nepalese organizations have remained grossly underutilized. This is mainly due to the lack of systematic human resource development plans, policies and practices. Nepalese banking sector is conscious in development and utilization of relatively competent work force, however banking missed to used their employees to it's maxim as the executive level decisions are made through head office and so employees feels their skills are yet under utilize though employees would be happy to contribute more to their organization if it appreciate their intellectuality, additionally employees expecting organization should keep keen concern for their potentiality also, simply they mean to say if organization fells we lack some skills then it should trained us.

But the tradition is "few employees get opportunity to go for training and most of the time the same person is getting opportunity to go again for training", so employees feel 
they are not fairly treated in upgrading their career, as a result banking people are focus to be in a position where they hold the discretion power in enhancing themselves from the side of finance, career development or educational growth, since training is almost given by banking sector.

Skills of employees if used are strongly positively correlated with the freedom of decision making, individual enjoy working in pressure, extent of immediate supervisor interest towards employees work and are highly co-operative, if opportunity for training are provided, equal opportunity on different factors are given, even individual feeling job pressure from every day job. And the level of communication is also not effective, it is believed by employees that there is a hierarchy level maintain.

\section{REFERENCES}

Agrawal, G.R. (1999). Organization and management in Nepal. Kathmandu: M.K. Publisher and Distributor. Agrawal, S., \& Ramaswami, S.N. (1993). Affective organizational commitment of sales person: An expanded model. Journal of Personal Selling \& Sales Management, 13 (2): 49-70.

Allen, N.J., \& Meyer, J.P. (1990). The measurement and antecedents of affective, continuance and normative commitment to the organization. Journal of Occupational Psychology, 63: 1-18.

Arana, N., Kushnir, T., \& Valency, A. (1986). Organizational commitment in a male-dominated profession. Human Relations, 39: 433-48.

Armstrong, M. (1999). Human resources management practice. London: Kogan .

Aven, F., Parker, B., \& McEvoy, G. (1993). Gender and attitudinal commitment to organizations: A meta analysis. Journal of Business Research, 26: 49-61.

Baird, J., Zelin, R., \& Marxen, D. (1998). Gender differences in the job attitudes of accountants. Mid-American Journal of Business, 13: 35-42.

Bielby, W., \& Bielby, D. (1989). Family ties: Balancing commitments to work and family in dual career households. American Sociological Review, 54: 74.

Bruning, N., \& Snyder, R. (1983). Sex and position as predictors of organizational commitment. Academy of Management Journal, 26: 485-91.

Dodd-McCue, D., \& Wright, G. (1996). Men, women, and attitudinal commitment: The effects of workplace experiences and socialization. Human Relations, 49: 1065-91.

Eagly, A. (1987). Reporting sex differences. American Psychologist, 42: 756-7.

Fry, L., \& Greenfeld, S. (1980). An examination between attitudinal differences between policewomen and policemen. Journal of Applied Psychology, 65: 123-6.

Gouldner, A.W. (1960). The norm of reciprocity. American Sociological Review, 25: 165-167

Greenberg J., \& Baron J. (2003). Behavior in organization: Understanding and managing the human side of work. USA: Pearson Upper Saddle, New Jersey

Greenberg, J., \& Baron, R.A. (2000). Behavior in organizations ( $7^{\text {th }}$ ed.). USA: Prentice-Hall, Upper Saddle River. 
Kabasakal, H., Boyacigiller, N., \& Erden, D. (1994). Organizational characteristics as correlates of women in middle and top management. Bogazici Journal: Review of Social, Economic, and Administrative Studies, 8 (1-2): 45-62.

Kaldenberg, D., Becker, B., \& Zvonkovic, A. (1995). Work and commitment among young professionals: A study of male and female dentists. Human Relations, 48 (11): 1355-77.

Kanter, R.M. (1968). Commitment and social organization: A study of commitment mechanisms in utopian communities. American Sociological Review, 33: 499-517.

Korabik, K., \& Rosen, H. (1995). The impact of children on women managers' career behavior and organizational commitment. Human Resource Management, 34: 513-28.

Lawer, E. J. (1992). Affective attachment to nested groups: A choice process theory. American Sociological Review, 57: 327-339.

Loden, M., \& Rosener, J. B. (1991). Workforce America! Managing employee diversity as a vital resource. Burr Ridge, IL: Irwin.

Marsden, P., Kalleberg, A., \& Cook, C. (1993). Gender differences in organizational commitment: Influences of work positions and family roles. Work and Occupations, 20 (3): 368-90.

Mathieu, J. E., \& Zajac, D. M. (1990). A review and meta-analysis of the antecedents, correlates, and consequences of organizational commitment. Psychological Bulletin, 108: 171-194.

Mathis, R.L., \& Jackson, J.H. (2006). Human resource management. OH: Thomson South/Western, Mason.

Meyer, J., \& Allen, N. (1997). Commitment in the workplace: Theory, research and application. Sage, Newbury Park, CA. Mottaz, C.J. (1988). Determinant of commitment. Human Relations, 41 (6): 467-82.

Meyer, J. P., \& Allen, N. J. (1991). A three-component conceptualization of organizational commitment. Human Resource Management Review, 1: 61-89.

Morrison, A. M. (1996). The new leaders: Leadership diversity in America. San Francisco: Jossey- Bass.

Mowday, R.T., Porter, R.W., \& Steers, R.M. (1982). Employee-organization linkages. The Psychology of Commitment, Absenteeism and Turnover. New York: Acedemic Press.

Ngo, H., \& Tsang, W. (1998). Employment practices and organizational commitment: Differential effects for men and women? International Journal of Organizational Analysis, 6 (3): 251-66.

Schuler, R.S., \& Jackson, S.E. (1999). Strategic human resource management. Oxford: Blackwell Publishing.

Siguaw, J., \& Honeycutt, E. (1995). An examination of gender differences in selling behaviors and job attitudes. Industrial Marketing Management, 24: 45-52.

Stallworth, H.L. (2003). Mentoring, organizational commitment and intentions to leave public accounting. Managerial Auditing Journal, 18 (5): 405-18.

Swailes S., June. (2002). Organizational commitment: A critique of the construct and measures. International Journal of Management Reviews, 4 (2).

US Bureau of Labor Statistics. (2000). Employment projections, [online]. Available at: http://stats.bls.gov

Wahn, J.C. (1998). Sex differences in the continuance component of organizational commitment. Group and Organization Management, 23 (3): 256-67.

Wiener, Y. (1982). Commitment in organizations: A normative view. Academy of Management Review, 7: 418-425. Zeytinoglu, I.U., Ozmen, O.T., Katrinli, A., Kabasakal, H., \& Arbak, Y. (2001). Factors affecting female managers' careers in Turkey. The Economics of Women and Work in the Middle East and North Africa: 225-45 
Appendix "A"

Description of Variables

\begin{tabular}{|l|l|}
\hline \multicolumn{1}{|c|}{ Personal Characteristics } & \\
\hline Gender & Male or female \\
\hline Autonomy Characteristics & \\
\hline Work pressure & $\begin{array}{l}\text { Possibility of taking own decisions on how to } \\
\text { do the task }\end{array}$ \\
\hline Skills used on the job & Pressure to get the work done in time \\
\hline \multicolumn{1}{|c|}{ Organizational Commitments } & $\begin{array}{l}\text { Ability and potential been appreciated by the } \\
\text { organization }\end{array}$ \\
\hline Normative commitment & $\begin{array}{l}\text { The degree to which an employee feels some } \\
\text { sense of obligation to remain with the organi- } \\
\text { zation (Allen and Meyer, 1990). }\end{array}$ \\
\hline & $\begin{array}{l}\text { The second component, interpreted as the nor- } \\
\text { mative commitment, e.g., I think it doesn't look } \\
\text { right if I quit this company. }\end{array}$ \\
\hline
\end{tabular}

\section{Appendix "B"}

Frequency, Mean, S.D of Gender

\begin{tabular}{|l|l|c|c|c|c|c|}
\hline Variables & & Frequency (N) & Mean & S.D & \% & Total \\
\hline Gender & & & 1.43 & .498 & & 109 \\
\hline & Male & 62 & & & 56.9 & \\
\hline & Female & 47 & & & 43.1 & \\
\hline
\end{tabular}

